\title{
Amorphous Molybdenum Sulfides as Hydrogen Evolution Catalysts
}

\author{
Carlos G. Morales-Guio and Xile $\mathrm{Hu}^{*}$
}

Laboratory of Inorganic Synthesis and Catalysis, Institute of Chemical Sciences and Engineering, École Polytechnique

Fédérale de Lausanne (EPFL), BCH 3305, Lausanne 1015, Switzerland. E-mail: xile.hu@epfl.ch

\section{CONSPECTUS:}

Providing energy for a population projected to reach 9 billion people within the middle of this century is one of the most pressing societal issues. Burning fossil fuels at a rate and scale that satisfy our near-term demand will irreversibly damage the living environment. Among the various sources of alternative and $\mathrm{CO}_{2}$-emission free energies, the sun is the only source that is capable of providing enough energy for the whole world. Sunlight energy, however, is intermittent and requires an efficient storage mechanism. Sunlightdriven water splitting to make hydrogen is widely considered as one of the most attractive methods for solar energy storage. Water splitting needs a hydrogen evolution catalyst to accelerate the rate of hydrogen production and to lower the energy loss in this process. Precious metals such as Pt are superior catalysts, but they are too expensive and scarce for large scale applications.

In this account, we summarize our recent research in the preparation, characterization, and application of amorphous molybdenum sulfide catalysts for the hydrogen evolution

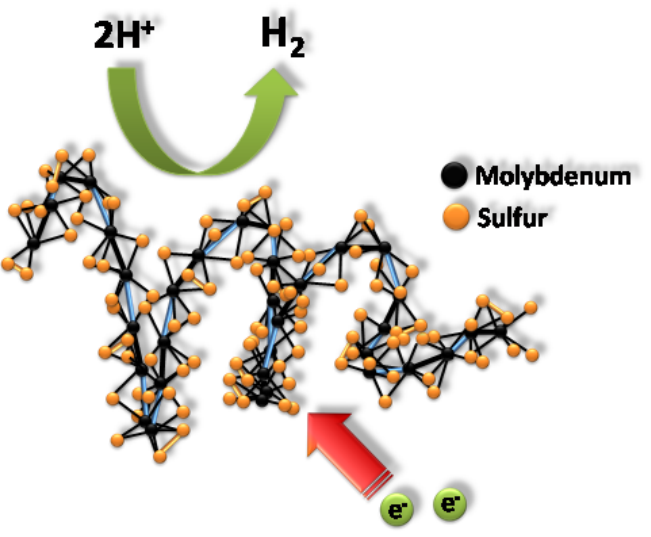
reaction. The catalysts can be synthesized by electrochemical deposition under ambient conditions from readily available and inexpensive precursors. The catalytic activity is among the highest for non-precious catalysts. For example, at a loading of $0.2 \mathrm{mg} / \mathrm{cm}^{2}$, the optimal catalyst delivers a current density of $10 \mathrm{~mA} / \mathrm{cm}^{2}$ at an overpotential of $160 \mathrm{mV}$. The growth mechanism of the electrochemically deposited film catalysts is revealed by an electrochemical quartz microcrystal balance study. While different electrochemical deposition methods produce films with different initial compositions, the active catalysts are the same and are identified as a "MoS ${ }_{2+x}$ " species. The activity of the film catalysts can be further promoted by divalent Fe, Co, and Ni ions, and the origins of the promotional effects have been probed. Highly active amorphous molybdenum sulfide particles are also prepared from simple wet chemical routes. Electron transport is sometimes slow in the particle catalysts, and an impedance model has been established to identify this slow electron transport. Finally, the amorphous molybdenum sulfide film catalyst has been integrated onto copper(I) oxide photocathode for photoelectrochemical hydrogen evolution. The conformal catalyst extracts efficiently the excited electrons to give an impressive photocurrent density of $-5.7 \mathrm{~mA} / \mathrm{cm}^{2}$ at $0 \mathrm{~V}$ vs. RHE. The catalyst also confers good stability.

\section{INTRODUCTION}

Solar irradiation reaching the surface of the Earth in a period of one hour is sufficient to satisfy the world's energy demand for one whole year at the current consumption rate. ${ }^{1}$ However, solar energy harvesting is often separated in time and location from consumption, demanding efficient energy storage and distribution systems at a scale commensurate with our energy demand. Electrochemical and photoelectrochemical production of hydrogen from water has long been considered as an attractive method for solar energy storage. ${ }^{2,3} \mathrm{Hy}-$ drogen is a clean energy vector that can be stored, distributed, and used on demand generating clean water as exhaust. ${ }^{4} \mathrm{Pt}$ group metals are the most efficient electrocatalysts for the hydrogen evolution reaction (HER; $2 \mathrm{H}^{+}+2 \mathrm{e}^{-} \rightarrow \mathrm{H}_{2}$ ). Unfortunately, these metals are among the rarest and most expensive elements on earth, making them unsuitable for energy storage at a global scale. Therefore, it is imperative to replace Ptgroup metals with materials made entirely of earth-abundant elements for HER. In addition, techno-economic analyses have suggested that a life-time of 15 or better 20 years for a solar hydrogen production device is required in order to achieve economically competitive $\mathrm{H}_{2}$ production. ${ }^{5}$ This requirement further limits the HER catalysts to only those of superior stability, simple maintenance, and minimum environmental impact during operation and at the end of the uselife. $^{6}$ 
a)

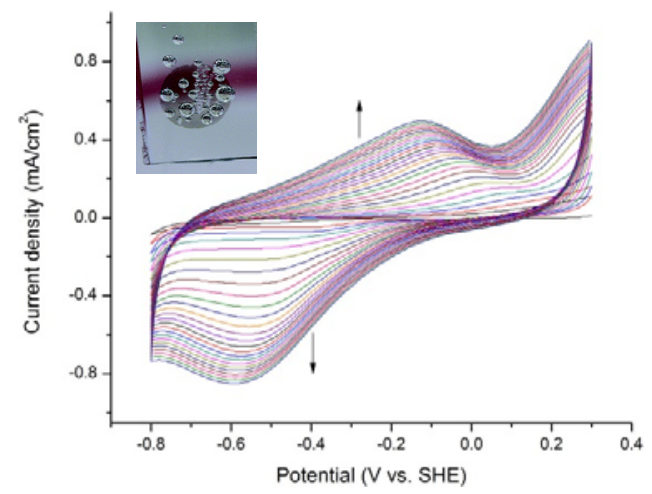

c)

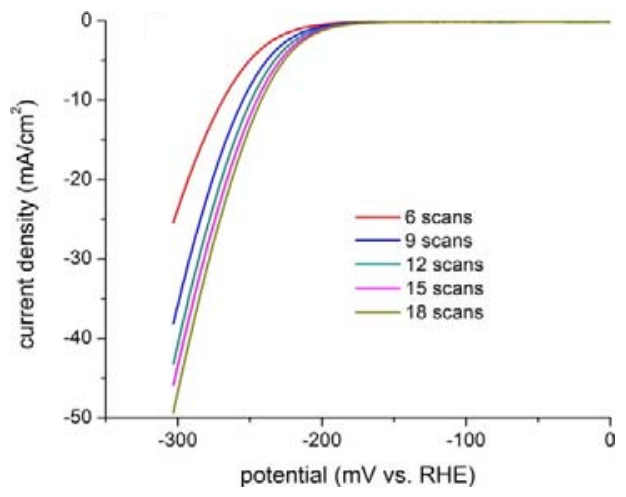

b)

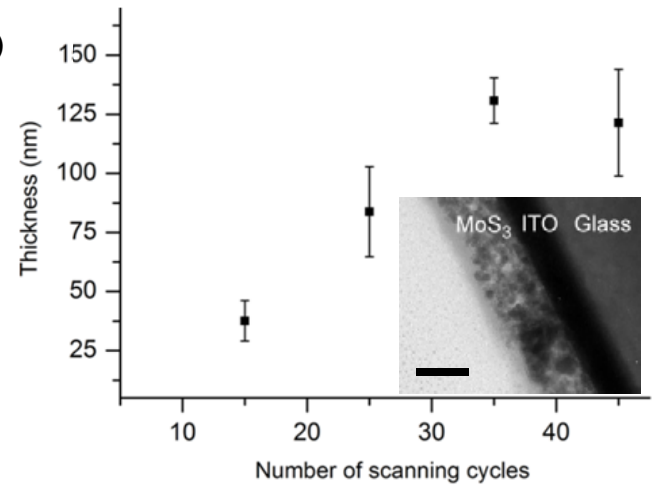

d)

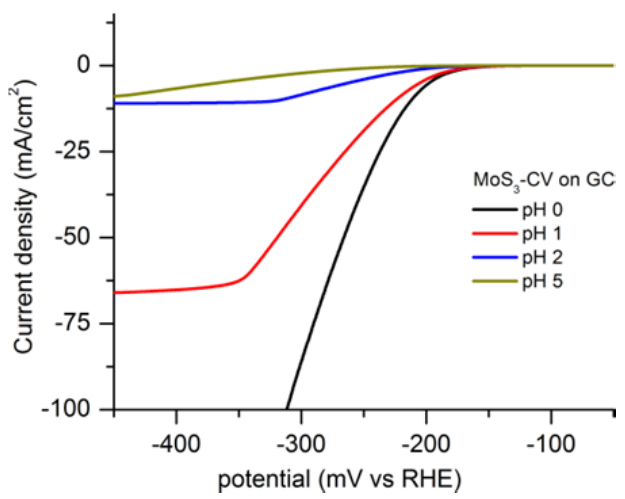

Figure 1. (a) Cyclic voltammograms during the deposition of a molybdenum sulfide film by cyclic voltammetry ( 25 cycles). Conditions: glassy carbon substrate, $\mathrm{NaClO}_{4}$ electrolyte $(0.1 \mathrm{M}), 2 \mathrm{mM}\left(\mathrm{NH}_{4}\right)_{2}\left[\mathrm{MoS}_{4}\right]$, scan rate $50 \mathrm{mV} / \mathrm{s}$. Inset: digital image of an amorphous molybdenum sulfide film on ITO during hydrogen evolution. (b) Thickness of $\mathrm{MoS}_{3}$-CV films as a function of scanning cycles. Inset: SEM image of a $\mathrm{MoS}_{3}-\mathrm{CV}$ film on ITO. The size bar corresponds to $50 \mathrm{~nm}$. (c) Polarization curves (at $\mathrm{pH}=0$ ) of $\mathrm{MoS}_{3}-\mathrm{CV}$ films made from different numbers of scanning cycles. The films were deposited on a rotating glassy carbon electrode. (d) Polarization curves of a MoS $3^{-}$ $\mathrm{CV}$ film on a rotating glassy carbon disk electrode recorded at different pHs. Adapted with permission from ref 18. Copyright 2011 Royal Society of Chemistry.

Hinnemann et al. identified the edge site of $\mathrm{MoS}_{2}$ as a promising hydrogen evolution catalyst in 2005 . $^{7}$ In principle, when the free energy of adsorbed atomic hydrogen is close to that of the reactant or product (i.e., $\Delta \mathrm{G}_{\mathrm{H}}^{0} \sim 0$ ), a material is potentially a good HER catalyst. ${ }^{8}$ They showed by DFT calculations that this holds for the active sites of hydrogen evolving enzymes such as nitrogenase and hydrogenase, and the edge site of $\mathrm{MoS}_{2}$. Subsequent experiments by Jaramillo et al. using $\mathrm{MoS}_{2}$ nano-crystals showed that the HER activity is indeed directly proportional to the edge length of the crystals but not to the surface area. ${ }^{9}$ Preferential exposure of edge sites has resulted in more active $\mathrm{MoS}_{2}$ electrocatalysts. ${ }^{10,11}$ Since the original studies of Hinneman et al. and Jaramillo et al., extensive efforts have been devoted to the preparation of nanostructured crystalline molybdenum sulfide materials for HER; these efforts have been reviewed by us and others. ${ }^{12-15}$ This account deals with a related but different type of molybdenum sulfides - the amorphous materials.

Amorphous molybdenum sulfides prove to be highly active and versatile catalysts for HER in acidic solutions. Amorphous materials are generally prepared at milder temperatures and with faster solidification processes than crystalline materials. Although amorphous molybdenum sulfides lack a long range order, they have short-range atomic arrangements ${ }^{16,17}$ that give rise to interesting catalytic properties. Our group discovered that amorphous molybdenum sulfides, known already since 1825 , are a highly active catalyst for HER. ${ }^{18}$ The simple and mild preparation methods along with the low cost of the precursor materials make this class of catalysts very attractive for the development of cost-effective electrochemical and photoelectrochemical hydrogen production devices. This account summarizes our work, from the first report in 2011 until a recent application in photoelectrochemical hydrogen production.

\section{DISCOVERY OF AMORPHOUS MOLYBDENUM} SULFIDE FILMS AS HER CATALYSTS

Sometime in 2009, we considered $\left[\mathrm{MoS}_{4}\right]^{2-}$ and its transition metal complexes $\left[\mathrm{M}\left(\mathrm{MoS}_{4}\right)_{2}\right]^{2-}$ as potential homogeneous HER catalysts. These compounds contain only sulfur ligands which are ubiquitous in the active sites of hydrogenase and nitrogenase enzymes. Additionally, they are either commercially available or easy to synthesize. Quickly we found that hydrogen evolution occurred from solutions containing these compounds. But more thorough investigations revealed that the molecular complexes decomposed under electrolysis conditions to yield active heterogeneous catalysts on the electrodes. ${ }^{19}$ This initiated our research in the preparation and application of these catalysts, later identified as amorphous molybdenum sulfides.

The initially optimized deposition method for amorphous molybdenum sulfide was cyclic voltammetry (CV). In a typical potential cycling experiment conducted for an aqueous solution of $\left[\mathrm{MoS}_{4}\right]^{2-}$, one reduction and one oxidation peak 
grew at -0.2 and $0.3 \mathrm{~V}$ vs. the reversible hydrogen electrode (RHE), respectively (Figure 1a); at the same time, a brownish film started to form on the electrode. ${ }^{18}$ The deposition worked on various conductive substrates such as fluorine-doped tin oxide (FTO), indium tin oxide (ITO) and glassy carbon (GC) electrodes. The thickness of the electrodeposited films increased with the number of scanning cycles up to a few hundred nanometers (Figure 1b). The current density for HER increased when the number of scanning cycles during deposition was increased, indicating a porous nature of the catalyst film (Figure 1c).

The HER catalytic activity of these molybdenum sulfide films, initially label as $\operatorname{MoS}_{\mathrm{x}}-\mathrm{CV}$, was first studied by linear sweep voltammetry. Figure $1 \mathrm{~d}$ shows the polarization curves of $\mathrm{MoS}_{3}-\mathrm{CV}$ on a rotating glassy carbon disc electrode. The $\mathrm{MoS}_{3}-\mathrm{CV}$ films displayed high catalytic activity for hydrogen evolution; the activity is higher at more acidic solutions. A typical film (made by 25 scanning cycles) on a glassy carbon disk gave current densities of 14 and $160 \mathrm{~mA} / \mathrm{cm}^{2}$ at a overpotential $(\eta)$ of 200 and $300 \mathrm{mV}$, respectively, at $\mathrm{pH}=0 .{ }^{18}$ The Tafel slope was $40 \mathrm{mV}$ per decade, indicative of a ratedetermining ion+atom step. Bulk electrolysis confirmed the quantitative Faradaic efficiency for HER with this catalyst. The catalyst was active for hydrogen evolution in a wide range of pHs (e.g., 0 to 13). ${ }^{18}$ The catalyst slowly deactivated in alkaline solutions but was stable in neutral and acidic solutions for many hours. ${ }^{19}$

At the time of our first report, the preparation of singlelayered, crystalline $\mathrm{MoS}_{2}$ electrocatalyst required sophisticated and energy intensive synthetic procedures including ultra-high vacuum conditions, reduction by $\mathrm{H}_{2} \mathrm{~S}$ streams, and annealing at high temperatures. ${ }^{9,20}$ Our electrodeposition method provided an easier and more scalable access to molybdenum sulfide based HER catalysts.

Characterization of the electrodeposited molybdenum sulfide films then revealed the amorphous nature of the films. No diffraction patterns were observed in electron and X-ray diffraction analyses. XPS analysis of the films indicated different compositions of the films depending on the potential region where the potential cycling experiment ended. For the films grown by a cycling experiment ending at an anodic potential, the XPS spectra resembled those of amorphous $\mathrm{MoS}_{3}$ particles. This catalyst was tentatively labeled as $\mathrm{MoS}_{3}-\mathrm{CV}$. For the films grown by a potential cycling experiment ending at a cathodic potential, the XPS spectra resembled those of $\mathrm{MoS}_{2}$. This catalyst was labeled as $\mathrm{MoS}_{2}-\mathrm{CV}$. The $\mathrm{MoS}_{3}-\mathrm{CV}$ and $\mathrm{MoS}_{2}-\mathrm{CV}$ films, however, exhibit similar HER activity, probably because they were activated to a similar catalyst during HER. A study was then undertaken to understand the formation and activation of these catalysts.

\section{GROWTH AND ACTIVATION OF AMORPHOUS} MOLYBDENUM SULFIDE CATALYSTS

The first few cyclic voltammograms during the deposition of amorphous molybdenum sulfide catalyst were featureless (Figure 1a). After several scans, a significant oxidative current was observed at the positive limit of the potential window, i.e., 0.5-0.7 V vs. RHE and a cathodic current was observed at the negative limit of the potential window, i.e., -0.3 to $-0.4 \mathrm{~V}$ vs. RHE. The growth of the catalyst was studied by Electrochemical Quartz Crystal Microbalance (EQCM). ${ }^{21}$ EQCM is a powerful tool to study electron transfer processes coupled to small changes of mass on an electrode. By setting a high gain on the frequency-to-voltage converter of the EQCM, it was possible to investigate in detail the mass changes during a single cycle of deposition. The deposition potential window was kept from 0.7 to $-0.4 \mathrm{~V}$ vs RHE while the starting point was chosen at $0.3 \mathrm{~V}$ since initial experiments showed no change of mass at this potential. Starting from $0.3 \mathrm{~V}$, the potential was first polarized positively to $0.7 \mathrm{~V}$, reversed from 0.7 to $-0.4 \mathrm{~V}$, and then reversed again to $0.3 \mathrm{~V}$. The mass change during the sixth deposition cycle is represented in Figure 2a. The mass of the film increased in the potential region of 0.3 to $0.7 \mathrm{~V}$, decreased in the region of 0.2 to $-0.2 \mathrm{~V}$, and increased again from -0.25 to $-0.4 \mathrm{~V}$. Based on previous studies of the electrochemistry of $\left[\mathrm{MoS}_{4}\right]^{2-22,23}$ the oxidative deposition process was attributed to the oxidation of $\left[\mathrm{MoS}_{4}\right]^{2-}$ according to eq 1 in Figure 2a. This oxidation produced not only $\mathrm{MoS}_{3}$ but also elemental S. The reductive corrosion from 0.2 to $-0.3 \mathrm{~V}$ consumed $70 \%$ of the newly deposited mass. Reduction of $\mathrm{MoS}_{3}$ to $\mathrm{MoS}_{2}$ would not amount to this weight loss. The reaction was assigned to the reverse reaction of eq 1, i.e., eq 2 in Figure 2a. Following this corrosion, a new reductive deposition took place between $-0.25 \mathrm{~V}$ and $-0.4 \mathrm{~V}$. This reaction was assigned to a reduction of $\left[\mathrm{MoS}_{4}\right]^{2-}$ to form amorphous $\mathrm{MoS}_{2}, \mathrm{SH}^{-}$, and $\mathrm{OH}^{-}$(eq 3, Figure 2a). The repetitive deposition and corrosion sequence during an individual scanning cycle resulted in a staircase growth of the film, as shown in Figure 3a (black trace).

EQCM was then applied to monitor film growth under various deposition conditions. ${ }^{21}$ It was found that higher concentration of $\left[\mathrm{MoS}_{4}\right]^{2-}$ in the deposition bath resulted in faster depositions. The potential window, especially the negative potential limit, also had an influence on the film growth. This influence was due to the potential dependent corrosion of $\mathrm{MoS}_{3}$ according to eq 2 at the cathodic potentials.

According to eqs 1-3, potential cycling would always produce a molybdenum sulfide film that is a mixture of amorphous $\mathrm{MoS}_{3}, \mathrm{MoS}_{2}$, and other sulfur species. On the other hand, electrolysis at a constant positive or negative potential would yield a "pure" amorphous $\mathrm{MoS}_{3}$ or $\mathrm{MoS}_{2}$ film. EQCM was used to monitor the film growth at $0.7 \mathrm{~V}$ and $-0.4 \mathrm{~V}$, respectively. Indeed, with constant potential electrolysis, only constant film growth, but not corrosion, was observed (Figure 3a). Oxidative deposition at $0.7 \mathrm{~V}$ is the fastest method to grow a film, followed by potential cycling between 0.7 and $0,4 \mathrm{~V}$. Reductive electrolysis at $-0.4 \mathrm{~V}$ is the slowest method to deposit a film. The activity of three films, grown by oxidative electrolysis, potential cycling, and reductive electrolysis was compared. For films of the same mass $\left(15 \mu \mathrm{g} / \mathrm{cm}^{2}\right)$, the activity was roughly the same. This was an indication that the three different films might be transformed to the same active species during catalysis.

Amorphous $\mathrm{MoS}_{3}$ films grown by oxidative electrolysis were then used for the benchmarking of the catalytic activity of this class of catalysts. Figure $3 \mathrm{~b}$ shows the activity of films at different loadings. Within the range of 26 to $198 \mu \mathrm{g} / \mathrm{cm}^{2}$, the activity increased with an increase in loading while the Tafel slopes remained at about $40 \mathrm{mV} / \mathrm{dec}$. At a loading of about $200 \mu \mathrm{g} / \mathrm{cm}^{2}$ which is the conventional loading of Pt in fuel cells, the catalyst gave a current density of $10 \mathrm{~mA} / \mathrm{cm}^{2}$ at an overpotential of $160 \mathrm{mV}$ (see Table 1 below for comparison of the electrochemical HER performance parameters for the different amorphous catalysts presented in this account). 
As different deposition methods yielded molybdenum sulfide films of different compositions, these films were analyzed by X-ray photoelectron spectroscopy (XPS) together with $\mathrm{MoS}_{2}$ microcrystals. ${ }^{21}$ For $\mathrm{MoS}_{2}$ crystals, the Mo $3 \mathrm{~d}$ spectrum is dominated by a doublet with a Mo $3 \mathrm{~d}_{5 / 2}$ binding energy of $229.5 \mathrm{eV}$ (Figure 3b). This doublet is attributed to the $\mathrm{Mo}^{\mathrm{IV}}$ ion in $\mathrm{MoS}_{2}$. A small doublet with a Mo $3 \mathrm{~d}_{5 / 2}$ peak at $232.7 \mathrm{eV}$ is also visible. This binding energy corresponds to that of $\mathrm{Mo}{ }^{\mathrm{VI}}$ ion, as in $\mathrm{MoO}_{3}$. An S 2 s peak of $226.7 \mathrm{eV}$ is also visible in the Mo region. The S $2 p$ spectrum shows one doublet with $\mathrm{S} 2 \mathrm{p}_{3 / 2}$ binding energy of $162.4 \mathrm{eV}$, corresponding to the sulfide $\left(\mathrm{S}^{2-}\right)$ ligand in $\mathrm{MoS}_{2}$. The Mo:S ratio is 1:1.9; the $\mathrm{Mo}^{\mathrm{VI}}$ ion contributes to $4 \%$ of the total Mo ions at the surface.

Potentiostatic anodic electrodeposition (AE) at $0.7 \mathrm{~V}$ vs. RHE yielded amorphous $\mathrm{MoS}_{3}$ plus some elemental sulfur according to eq 1 . The XPS spectra of this film (Figure 2c) show one Molybdenum doublet with a $3 \mathrm{~d}_{5 / 2}$ binding energy of $229.8 \mathrm{eV}$ corresponding to $\mathrm{Mo}^{\mathrm{IV}}$ in $\mathrm{MoS}_{3}$. Three different sulfur states were used to fit the $\mathrm{S} 2 \mathrm{~s}$ and $\mathrm{S} 2 \mathrm{p}$ spectra. ${ }^{21}$ The $\mathrm{S}$ $2 \mathrm{p}_{3 / 2}$ peaks have binding energies of $163.6,162.9$, and $162 \mathrm{eV}$, corresponding to elemental $\mathrm{S}(0)$, bridging $\mathrm{S}_{2}{ }^{2-}$, and terminal

a)

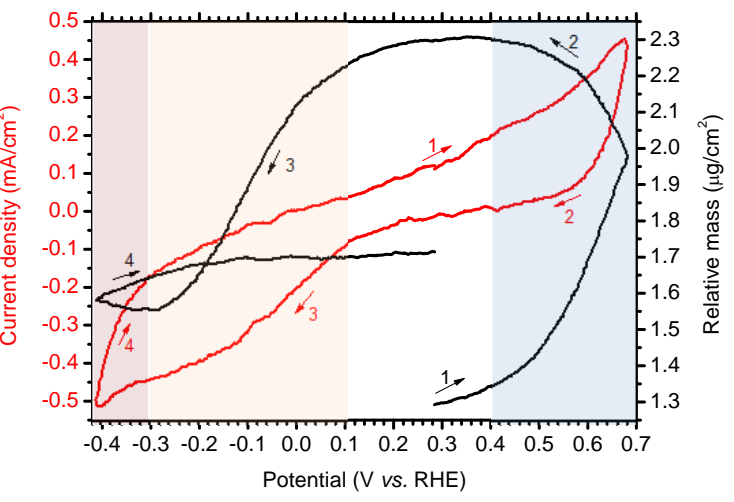

Chemical reactions related to film growth and corrosion:

1) Oxidative deposition of $\mathrm{MoS}_{3}$ from $\left[\mathrm{MoS}_{4}\right]^{2-}$ :

$$
\left[\mathrm{MoS}_{4}\right]^{2-} \rightarrow \mathrm{MoS}_{3}+\frac{1}{8} S_{8}+2 e^{-}
$$

2) Reductive corrosion by reverse reaction:

$$
\mathrm{MoS}_{3}+\frac{1}{8} S_{8}+2 e^{-} \rightarrow\left[\mathrm{MoS}_{4}\right]^{2-}
$$

3) Reductive deposition of $\mathrm{MoS}_{2}$ from $\left[\mathrm{MoS}_{4}\right]^{2-}$ :

$$
\left[\mathrm{MoS}_{4}\right]^{2-}+2 \mathrm{H}_{2} \mathrm{O}+2 e^{-} \rightarrow \mathrm{MoS}_{2}+2 \mathrm{HS}^{-}+2 \mathrm{HO}^{-}
$$

$\mathrm{S}^{2-}$, respectively. The relative intensities of the peaks at 162.9 and $162.0 \mathrm{eV}$, however, might not be used to accurately deduce the $\mathrm{S}_{2}{ }^{2-} / \mathrm{S}^{2-}$ ratio in the sample due to possible overlaps. The shapes and binding energies of the XPS spectra of the films are similar to those of previously reported amorphous $\mathrm{MoS}_{3}$ particles and films. ${ }^{16,22}$ The Mo:S ratio is $1: 3.6$, consistent with the presence of residual elemental sulfur predicted by eq 1 . The XPS spectra of films made by cathodic electrolysis and potential cycling methods also revealed compositions that were consistent with eqs $1-3 .^{21}$
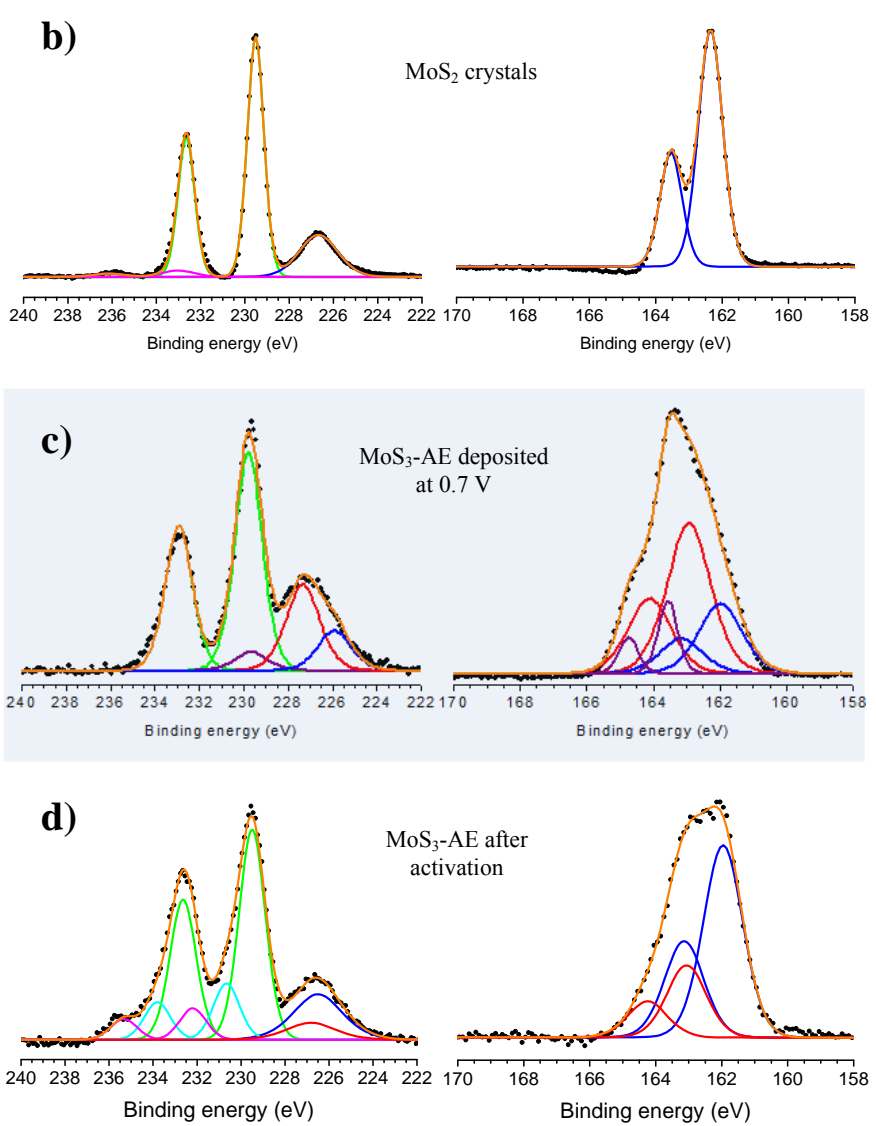

Figure 2. (a) Top: The evolution of current (red line) and film mass (black line) during a potential scanning cycle for the electrochemical deposition of a molybdenum sulfide film. Arrows and numbers indicated the direction of potential scanning. Conditions: Au substrate, $\mathrm{NaClO}_{4}$ electrolyte $(0.1 \mathrm{M}), 2 \mathrm{mM}\left(\mathrm{NH}_{4}\right)_{2}\left[\mathrm{MoS}_{4}\right]$, scan rate $50 \mathrm{mV} / \mathrm{s}^{1}$. Bottom: Chemical reactions related to film growth and corrosion. (b) XPS spectra of $\mathrm{MoS}_{2}$ microcrystals. Left: Mo 3d and S 2s region, experimental data ( $\left.\cdots \cdot\right)$, fitting envelope $(-), \mathrm{MoS}_{2}(-), \mathrm{MoO}_{3}(-$ ), $S^{2-} 2$ s (一). Right: S 2p region, experimental data (‥), fitting envelope (-), $\mathrm{MoS}_{2}(-)$. (c) XPS spectra of a MoS 3 -AE film growth by potentiostatic anodic electrodeposition at $0.7 \mathrm{~V}$ vs. RHE. Left: Mo 3d and S 2s region, experimental data ( …), fitting envelope ( - ), $\mathrm{MoS}_{3}(-), \mathrm{S}^{0} 2 \mathrm{~s}(-), \mathrm{S}_{2}{ }^{2-} 2 \mathrm{~s}(-), \mathrm{S}^{2-} 2 \mathrm{~s}(-)$. Right: $\mathrm{S} 2 \mathrm{p}$ region, experimental data $(\cdots)$, fitting envelope (-), $\mathrm{S}^{0}(-), \mathrm{S}_{2}{ }^{2-}(-), \mathrm{S}^{2-}(-)$. (d) XPS spectra for $\mathrm{MoS}_{3}$-AE after activation for HER. Left: Mo 3d region, experimental data $(\cdots \cdot)$, fitting envelope $(-)$, Mo ${ }^{\mathrm{A}} \mathrm{S}_{\mathrm{n}}(-)$,

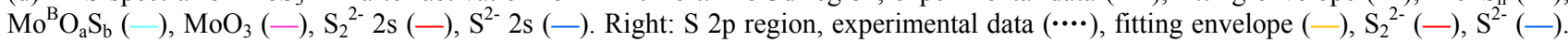
Adapted with permission from ref 21. Copyright 2013 American Chemical Society. 
a)

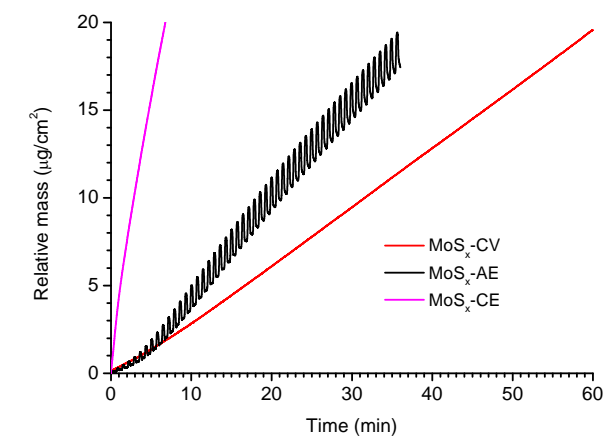

b)

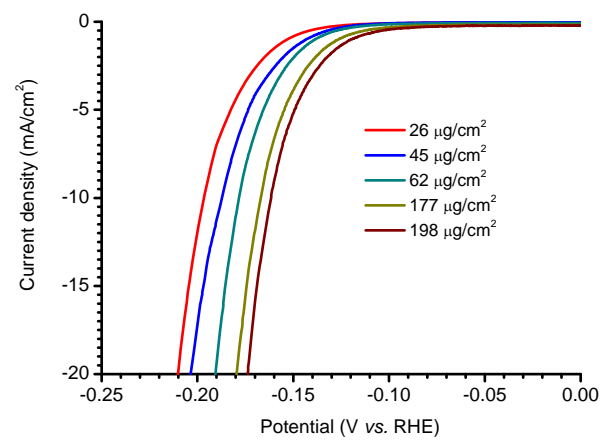

Figure 3. (a) The time-dependent growth of molybdenum sulfide films deposited by three different deposition methods: anodic electrolysis at $0.7 \mathrm{~V}(\mathrm{AE})$, cathodic electrolysis $(\mathrm{CE})$ at $-0.4 \mathrm{~V}$, and cyclic voltammetry $(\mathrm{CV})$ between 0.7 and $-0.4 \mathrm{~V}$. (b) Stable (10 $\left.{ }^{\text {th }}\right)$ polarization curves in $1.0 \mathrm{M} \mathrm{H}_{2} \mathrm{SO}_{4}$ for $\mathrm{MoS}_{3}$ films at different loadings. Conditions: Au substrate; scan rate, $5 \mathrm{mV} / \mathrm{s}^{1}$. Adapted with permission from ref 21. Copyright 2013 American Chemical Society.

The activation of the $\mathrm{MoS}_{3}$-AE film was followed by XPS and EQCM. Immersing the as-prepared film in $1.0 \mathrm{M} \mathrm{H}_{2} \mathrm{SO}_{4}$ seemed to remove most of the residual elemental $\mathrm{S}$, indicated by a decrease of the Mo:S ratio to $1: 3.2$ and a mass loss of $7 \%{ }^{21}$ The acid washed $\mathrm{MoS}_{3}$ film was then transformed to the active catalyst by a linear potential sweep. A mass decrease of $17 \%$ was observed at potentials just positive of the onset potential for HER (Figure 4). This mass decrease is consistent with the removal of slightly less than one equivalent of $\mathrm{S}$ from $\mathrm{MoS}_{3}$. Figure 2d shows the XPS spectra for the activated catalyst. The Mo 3d spectrum contains small peaks due to $\mathrm{Mo}^{\mathrm{IV}}$ in Mo oxysulfide and $\mathrm{Mo}^{\mathrm{VI}}$ in $\mathrm{MoO}_{3}$ besides a dominating doublet due to $\mathrm{Mo}^{\mathrm{IV}}$ in Mo sulfide. The $\mathrm{S} 2 \mathrm{p}$ spectrum shows two doublets due to $\mathrm{S}^{2-}$ and $\mathrm{S}_{2}{ }^{2-}$. The Mo:S ratio was close to $1: 2$, and the relative intensity of $\mathrm{S}^{2-}$ and $\mathrm{S}_{2}{ }^{2-}$ peaks was about 70 to 30 . Importantly, the active species for amorphous molybdenum sulfide films made by cathodic electrolysis and potential cycling have the same XPS spectra. Therefore, all these films are transformed to the same active catalyst during HER. This catalyst is labeled as $\mathrm{MoS}_{2+\mathrm{x}}$ because it has a $\mathrm{Mo} / \mathrm{S}$ ratio close to 2 but a S 2 p XPS spectrum that is distinct from that of crystalline $\mathrm{MoS}_{2}$ and that indicates both $\mathrm{S}_{2-}$ and $\mathrm{S}_{2}{ }^{2-}$ units.

The amorphous $\mathrm{MoS}_{2+\mathrm{x}}$ catalyst should be distinguished then from the ubiquitous $\mathrm{MoS}_{2}$ nanocrystals by its different structure (amorphous versus crystalline) and XPS properties (vide supra). While metallic edge sites are the active sites for

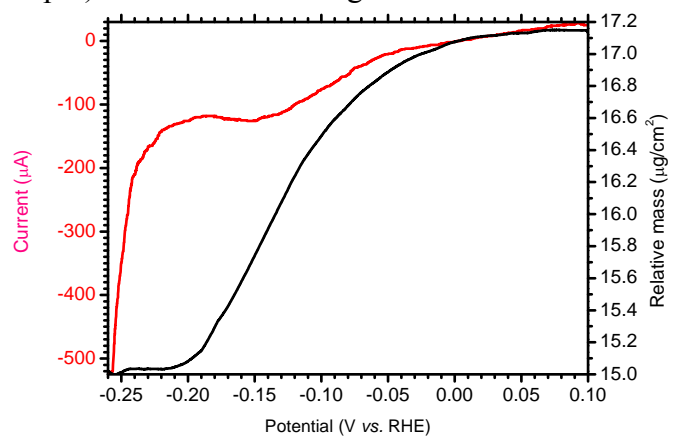

Figure 4. Mass change during the activation of a $\mathrm{MoS}_{3}$ film in the first linear sweep scan. Conditions: Au substrate, $\mathrm{H}_{2} \mathrm{SO}_{4}$ electrolyte $(1 \mathrm{M})$, scan rate $5 \mathrm{mV} / \mathrm{s}$. Adapted with permission from ref 21. Copyright 2013 American Chemical Society.
HER catalyzed by $\mathrm{MoS}_{2}$ nanoparticles, there is no defined edges in amorphous $\mathrm{MoS}_{2+x}$ films. However, chemically speaking, the edge sites in $\mathrm{MoS}_{2}$ crystals can be considered as Mo and $\mathrm{S}$ sites that are coordinatively unsaturated. These unsaturated sites can adsorb hydrogen and mediate HER. In the $\mathrm{MoS}_{2+x}$ films, there shall be plenty of such unsaturated, "defect" Mo and S sites due to its amorphous nature. As a consequence, these amorphous films exhibit remarkable high HER activity.

PROMOTION OF THE HER ACTIVITY OF AMORPHOUS MOLYBDENUM SULFIDE FILMS BY FIRST-ROW TRANSITION METAL IONS

Thin films active for HER were also deposited from aqueous solution of $\left(\mathrm{NH}_{4}\right)_{2}\left[\mathrm{Co}\left(\mathrm{MoS}_{4}\right)_{2}\right]$ by cyclic voltammetry. The optimized deposition conditions were analogous to those for the deposition of amorphous molybdenum sulfide films. Similar films could be made from solutions containing a mixture of $\mathrm{CoCl}_{2}$ and $\left(\mathrm{NH}_{4}\right)_{2}\left[\mathrm{MoS}_{4}\right]$. Presumably, $\left(\mathrm{NH}_{4}\right)_{2}\left[\mathrm{Co}\left(\mathrm{MoS}_{4}\right)_{2}\right]$ formed in this mixture was the precursor for the films. Deposition from solutions of $\mathrm{CoCl}_{2}$ and $\left(\mathrm{NH}_{4}\right)_{2}\left[\mathrm{MoS}_{4}\right]$ allowed the variance of the Co to Mo ratio in the deposition bath. XPS analysis of the films revealed the presence of Mo, Co and S. The Co-Mo-S films are active for HER; in fact, their activity is higher than the $\mathrm{MoS}_{2+\mathrm{x}}$ catalyst. ${ }^{24}$ The addition of cobalt and nickel to $\mathrm{MoS}_{2}$ nanoparticles was known to enhance their catalytic activity for the hydrodesulfurization reaction. ${ }^{25}$ Bonde et al. also showed that $\mathrm{Co}^{2+}$ promoted $\mathrm{MoS}_{2}$ and $\mathrm{WS}_{2}$ nanocrystals for HER. ${ }^{20}$ This prompted us to investigate the promotion of the HER activity of $\mathrm{MoS}_{2+\mathrm{x}}$ by $\mathrm{Co}$ and several other first-row transition metals ions. The ions were in the oxidation state of +2 .

Figure 5 shows the catalytic activity of the ternary M$\mathrm{MoS}_{2+\mathrm{x}}$ films $(\mathrm{M}=\mathrm{Mn}, \mathrm{Fe}, \mathrm{Co}, \mathrm{Ni}, \mathrm{Cu}$, and $\mathrm{Zn})$ at $\mathrm{pH} 7$ and $0{ }^{26} \mathrm{Fe}, \mathrm{Co}$ and $\mathrm{Ni}$ ions are effective promoters, while $\mathrm{Mn}, \mathrm{Cu}$ and $\mathrm{Zn}$ ions give no or only a small promotion. At $\mathrm{pH}=7$, the best promoter is $\mathrm{Co}^{2+}$, which gives $\mathrm{MoS}_{2+\mathrm{x}}$ a 5 times increase in current density at $\eta=200 \mathrm{mV}$. At $\mathrm{pH}=0$, the best promoter is $\mathrm{Fe}^{2+}$, which gives $\mathrm{MoS}_{2+\mathrm{x}}$ a two-fold increase in current density at both $\eta=200 \mathrm{mV}$ and $\eta=150 \mathrm{mV}$. In general, the promotion by the same ion is stronger at $\mathrm{pH}=7$ than at $\mathrm{pH}=$ 0 . 
a)

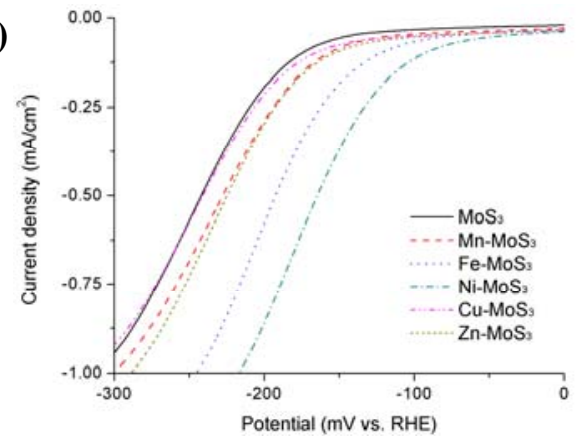

c)

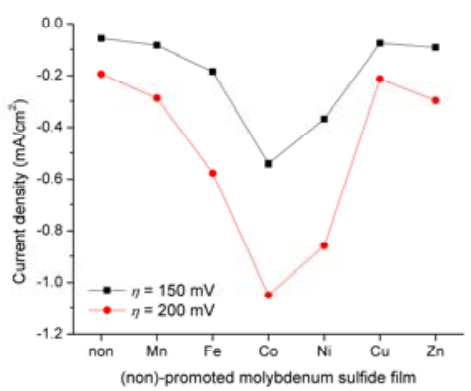

b)

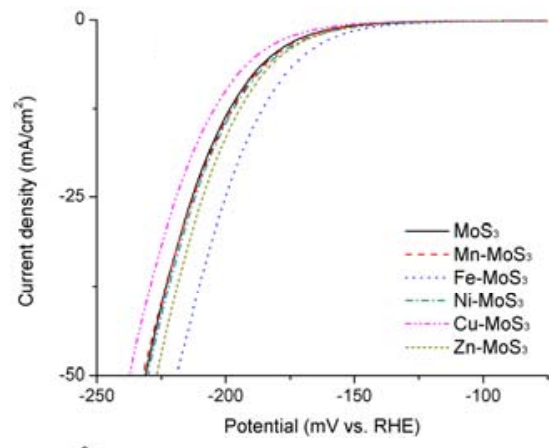

d)

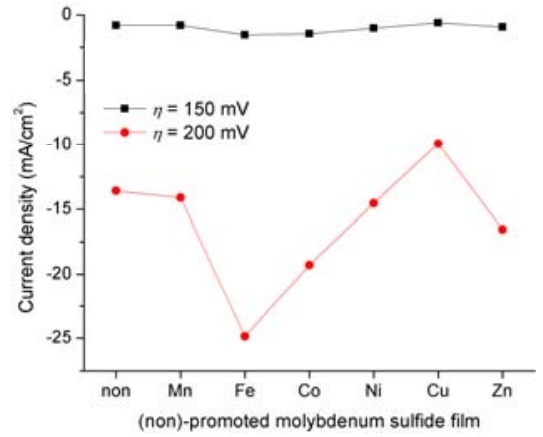

Figure 5. (a) and (b): Polarization curves of unpromoted and $\mathrm{M}$-promoted $(\mathrm{M}=\mathrm{Mn}, \mathrm{Fe}, \mathrm{Ni}, \mathrm{Cu}$ or $\mathrm{Zn}) \mathrm{MoS}_{2+\mathrm{x}}$ films on glassy carbon at $\mathrm{pH}=7$ (a) and 0 (b). The M-promoted films were deposited from aqueous solutions of $\mathrm{M}^{2+}(0.67 \mathrm{mM})$ and $\left[\mathrm{MoS}_{4}\right]^{2-}(2 \mathrm{mM})$ by 25 consecutive cyclic voltammetric scans. (c) and (d): Comparison of current densities of unpromoted and promoted $\mathrm{MoS}_{2+\mathrm{x}}$ films on glassy carbon at $\mathrm{pH}=7$ (c) and 0 (d) at $\eta=150 \mathrm{mV}$ and $200 \mathrm{mV}$. Adapted with permission from ref 24. Copyright 2012 Royal Society of Chemistry.

The origin of the promotional effects of $\mathrm{Fe}, \mathrm{Co}$, and $\mathrm{Ni}$ ions was probed. The morphology and thickness of the $\mathrm{MoS}_{2+\mathrm{x}}$ and

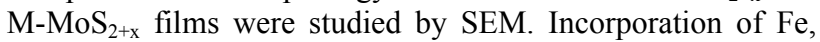
$\mathrm{Co}$ or $\mathrm{Ni}$ ions resulted in appreciable increase in the porosity of the film. The thickness of the film also increases considerably after the incorporation of $\mathrm{Fe}, \mathrm{Co}$ or $\mathrm{Ni}$ ions. The unpromoted $\mathrm{MoS}_{2+\mathrm{x}}$ film had a maximum thickness of $150 \mathrm{~nm}$, while the $\mathrm{Fe}, \mathrm{Co}$, and Ni-promoted films were up to $500 \mathrm{~nm}$ in thickness under the same deposition conditions. The compositions of the films were determined by XPS and inductively coupled plasma atomic emission spectroscopy (ICP-AES). It was shown that only a low amount of $\mathrm{Mn}, \mathrm{Cu}$, or $\mathrm{Zn}$ ions (1$5 \%$ ) could be incorporated to the $\mathrm{MoS}_{2+x}$ films, which was the reason for their lack of promotion in the activity of these films. On the other hand, a significant amount of $\mathrm{Fe}, \mathrm{Co}$, and $\mathrm{Ni}$ ions could be incorporated. From a deposition bath containing a 1:3 ratio of $\mathrm{MCl}_{2}(\mathrm{M}=\mathrm{Fe}, \mathrm{Co}, \mathrm{Ni})$ to $\left(\mathrm{NH}_{4}\right)_{2}\left[\mathrm{MoS}_{4}\right], \mathrm{M}-\mathrm{MoS}_{2+\mathrm{x}}$ films with a M:Mo ratio between 1:3 and 1:4 could be deposited. In addition, the $\mathrm{M}-\mathrm{MoS}_{2+\mathrm{x}}$ films $(\mathrm{M}=\mathrm{Fe}, \mathrm{Co}, \mathrm{Ni})$ had a Mo content that was about 3 times that of unpromoted $\mathrm{MoS}_{2+\mathrm{x}}$ film grown under analogous conditions. This indicates that $\mathrm{Fe}$, $\mathrm{Co}$, and $\mathrm{Ni}$ ions promoted the growth of the $\mathrm{MoS}_{2+\mathrm{x}}$ films. The relative electrochemical surface areas of the unpromoted and $\mathrm{Fe}, \mathrm{Co}$, and Ni-promoted $\mathrm{MoS}_{2+\mathrm{x}}$ films were compared using their double layer capacitance. The capacitance could be determined by cyclic voltammetry. The $\mathrm{Fe}, \mathrm{Co}$, and Ni-promoted $\mathrm{MoS}_{2+\mathrm{x}}$ films had surface areas that were 1.4 to 3.3 times of that of the unpromoted $\mathrm{MoS}_{2+\mathrm{x}}$ film.

The above data indicate that $\mathrm{Fe}, \mathrm{Co}$, and $\mathrm{Ni}$ ions promote the growth of the $\mathrm{MoS}_{2+\mathrm{x}}$ film, increasing its thickness, loading, porosity, and surface area. This increase is on the order of 3 fold. At $\mathrm{pH}=0$, the increase of activity by promotion is on the order of 3 fold as well. Therefore, the promotion at $\mathrm{pH}=0$ is mostly associated with film growth. At $\mathrm{pH}=7$, however, the promoted films are 5-12 times more active. Clearly at higher $\mathrm{pHs}, \mathrm{Fe}, \mathrm{Co}$, and $\mathrm{Ni}$ ions seem to increase the intrinsic activity of $\mathrm{MoS}_{2+\mathrm{x}}$ for HER. It is hypothesized that these ions modify the absorption energy of hydrogen at the unsaturated Mo and $\mathrm{S}$ sites which are the active sites for HER. Similar promotional effects are known for the hydrodesulfurization reaction of natural gas and refined petroleum products and the HER, where transition metal ions such as $\mathrm{Co}^{2+}$ significantly enhance the activity of $\mathrm{MoS}_{2}$ nanoparticles. ${ }^{12,20,25,27}$ DFT calculations suggest that Co ions bind to inactive sulfur edge sites, making them catalytically active. ${ }^{20}$

\section{CHEMICALLY SYNTHESIZED} MOLYBDENUM SULFIDE PARTICLES

AMORPHOUS

While highly active amorphous molybdenum sulfide films could be prepared by electrodeposition as described in the previous sections, the preparation of similarly active nanoparticles through chemical synthesis is also desirable. Chemical synthesis tends to be more scalable and can allow the deposition of catalyst films without using electrochemistry which might be unsuitable for certain substrates. As our earlier work showed that amorphous $\mathrm{MoS}_{3}$ film could be activated to form the active $\mathrm{MoS}_{2+\mathrm{x}}$ catalyst, we thought amorphous $\mathrm{MoS}_{3}$ particles might have the same property. Amorphous $\mathrm{MoS}_{3}$ particles are normally prepared by acidification of tetrathiomolybdate solutions. ${ }^{28}$ We found that similar particles could be obtained by acidification of a solution of $\mathrm{MoO}_{3}$ and $\mathrm{Na}_{2} \mathrm{~S}$, making the synthesis more economical. ${ }^{29}$ XPS spectra of the resulting $\mathrm{MoS}_{3}$ particles resembles those of known $\mathrm{MoS}_{3}$ samples. ${ }^{16}$ The Mo to $\mathrm{S}$ ratio is 1 to 3 . Figure $5 \mathrm{a}$ shows the TEM image of the 
particles. Electron diffraction study confirmed the amorphous nature of the particles.

The chemically synthesized amorphous $\mathrm{MoS}_{3}$ particles were deposited on various electrodes by drop-casting and spraycasting methods. The resulting electrodes had rather good activity for HER at $\mathrm{pH}=0$. For example, at a loading of 32 $\mu \mathrm{g} / \mathrm{cm}^{2}$, a $\mathrm{MoS}_{3}$-modified glassy carbon electrode gave a current density of $2.3 \mathrm{~mA} / \mathrm{cm}^{2}$ at $\eta=200 \mathrm{mV}$. This activity is comparable to that of many nanostructured and crystalline $\mathrm{MoS}_{2}$ particles, although it is only $1 / 8$ of that of an amorphous $\mathrm{MoS}_{2+\mathrm{x}}$ film at a similar loading. ${ }^{21}$ Importantly, the amorphous $\mathrm{MoS}_{3}$ particles also underwent an activation process to form an active species that has similar XPS spectra as the $\mathrm{MoS}_{2+\mathrm{x}}$ species formed from amorphous $\mathrm{MoS}_{3}$ films. This indicates that the active species from chemically synthesized $\mathrm{MoS}_{3}$ particles is also $\mathrm{MoS}_{2+\mathrm{x}}$.

a)
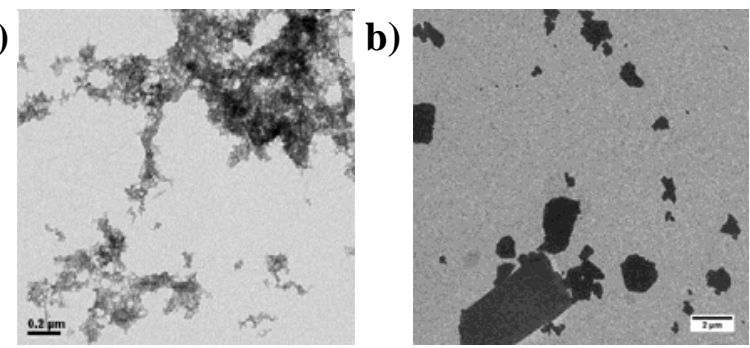

c)

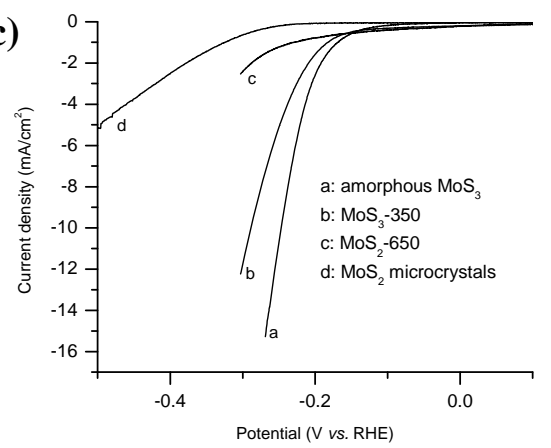

Figure 6. (a) and (b): TEM images of amorphous $\mathrm{MoS}_{3}$ particles (a) and amorphous $\mathrm{MoS}_{3}$ particles after annealing at $350{ }^{\circ} \mathrm{C}$ for $1 \mathrm{~h}$ (b). (c) Polarization curves of carbon paste electrodes modified with a layer of $\mathrm{MoS}_{\mathrm{x}}$-species. The measurements were conducted at $\mathrm{pH}=0\left(1.0 \mathrm{M} \mathrm{H}_{2} \mathrm{SO}_{4}\right)$; scan rate: $5 \mathrm{mV} / \mathrm{s}$. Adapted with permission from ref 29. Copyright 2012 Royal Society of Chemistry.

Annealing of amorphous $\mathrm{MoS}_{3}$ particles resulted in significant change in composition and crystallinity. When annealed at $350{ }^{\circ} \mathrm{C}$ for $1 \mathrm{~h}$, the particle size increased from below 100 $\mathrm{nm}$ to about $1 \mu \mathrm{m}$ (compare Figure $6 \mathrm{a}$ and $6 \mathrm{~b}$ ), and the particles became polycrystalline. The composition remained close to $\mathrm{MoS}_{3}$. When further annealed at $650{ }^{\circ} \mathrm{C}$ for $30 \mathrm{~min}$, the particles became single crystalline $\mathrm{MoS}_{2}$ of $100 \mathrm{~nm}$ in width and several $\mu \mathrm{m}$ in length. Even larger microcrystals of $\mathrm{MoS}_{2}$ could be purchased from Aldrich. The activity of various molybdenum sulfide particles was compared using a same carbon paste electrode as the substrate (Figure 6c). The amorphous $\mathrm{MoS}_{3}$ particles had the highest activity, followed by polycrystalline $\mathrm{MoS}_{3}$ (annealed at $350{ }^{\circ} \mathrm{C}$, labeled as $\mathrm{MoS}_{3}-$ 350 ), and then the small $\mathrm{MoS}_{2}$ single crystal particles (annealed at $650{ }^{\circ} \mathrm{C}$, labeled as $\left.\mathrm{MoS}_{2}-650\right)$. The larger $\mathrm{MoS}_{2}$ microcrystals had the lowest activity. The activity trend is a)

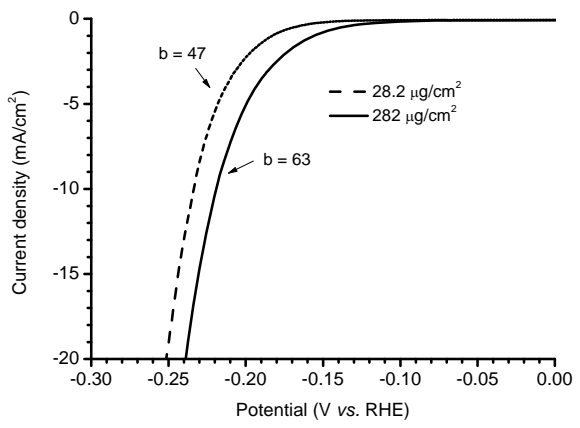

b)

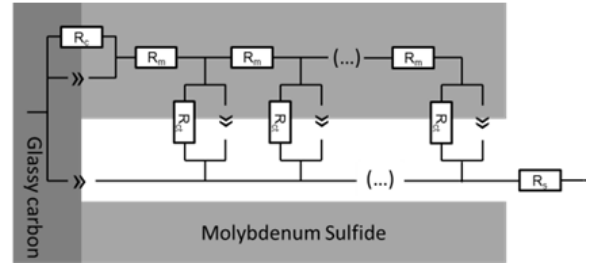

c)

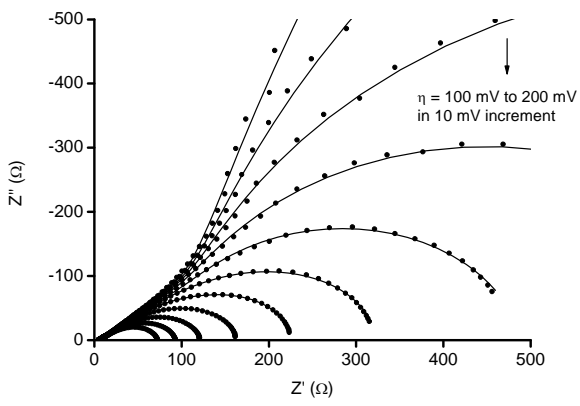

Figure 7. (a) Polarization curve of glassy carbon electrode modified with two different loadings of amorphous $\mathrm{MoS}_{3}$ particles at $\mathrm{pH}=0$. (b) Equivalent circuit using a transmission line model. $R_{c}$ represents the resistance at the contact between the electrode and the catalyst film. $R_{m}$ is the non-negligible electronic resistance of $\mathrm{MoS}_{\mathrm{x}}$. $\mathrm{R}_{\mathrm{ct}}$ is the charge transfer resistance. The layer structure of the film is accounted for by repeating units of $R_{m}$ in series with $R_{c t}$. (c) The Nyquist plot and fitting for the impedance response of the $\mathrm{MoS}_{3}$ modified electrode at a loading of $282 \mu \mathrm{g} / \mathrm{cm}^{2}$. Adapted with permission from ref 30. Copyright 2013 Royal Society of Chemistry.

consistent with our hypothesis for the high activity of amorphous molybdenum sulfide catalysts. In the amorphous $\mathrm{MoS}_{3}$ particles, there are a large number of unsaturated Mo and $\mathrm{S}$ sites that might catalyze HER. When annealed at high temperatures, the particles become more crystalline so that there are fewer such "defect" sites. Finally, the largest crystals have the least amount of defect sites.

The Tafel slopes of chemically synthesized amorphous $\mathrm{MoS}_{3}$ particles were larger than those of electrochemically deposited $\mathrm{MoS}_{2+x}$ films. The latter are constantly about 40 $\mathrm{mV} / \mathrm{dec}$ while the former are as high as $63 \mathrm{mV} / \mathrm{dec}$. Moreover, a higher loading of $\mathrm{MoS}_{3}$ particles led to a higher Tafel slope. This is illustrated in Figure 7a. At a loading of $28 \mu \mathrm{g} / \mathrm{cm}^{2}$, a glassy carbon electrode modified by $\mathrm{MoS}_{3}$ particles gave a Tafel slope of $47 \mathrm{mV} / \mathrm{dec}$; at a loading of $282 \mu \mathrm{g} / \mathrm{cm}^{2}$, an analogous electrode gave a Tafel slope of $63 \mathrm{mV} / \mathrm{dec}$. We thought the higher Tafel slopes observed for $\mathrm{MoS}_{3}$ particles, especially at higher loadings, might be due to slow electron transport in this type of materials that have modest electronic 
conductivity. This was confirmed by electrochemical impedance spectroscopy. ${ }^{30}$ The equivalent circuit that fits the impedance data is shown in Figure $7 \mathrm{~b}$. This is a transmission line model that have been previously used to model porous materials with intermediate resistivity, e.g., $\mathrm{TiO}_{2}$ films in Grätzel cells. ${ }^{31}$ The porous and resistive nature of $\mathrm{MoS}_{3}$ particles is accounted for by repeating units of $R_{m}$ in series with $R_{c t}$, where $R_{m}$ represents a non-negligible electronic resistance of $\mathrm{MoS}_{3}$, and $\mathrm{R}_{\mathrm{ct}}$ represents the charge transfer resistance due to HER. Figure 7c shows the fitting of the Nyquist plot for the HER by $\mathrm{MoS}_{3}$ particles at the loading of $282 \mu \mathrm{g} / \mathrm{cm}^{2}$. A notable feature is the $45^{\circ}$ line observed in the high frequency region which originates from the slow electron transport process. Consequently, this feature was designated as a finger print for slow electron transport in an electrocatalytic process. The fitting of impedance data also yielded charge transfer resistance, $\mathrm{R}_{\mathrm{ct}}$, which is inversely proportional to HER rate. The linear fitting of the plot of $\log \mathrm{R}_{\mathrm{ct}}$ Vs. overpotential gives the charge transfer Tafel slope. It was found that the slopes were about $40 \mathrm{mV}$ for $\mathrm{MoS}_{3}$ particles at both low and high loadings. Thus, the higher apparent Tafel slopes obtained from voltammetric data reflected not only the electrode kinetics but also the slow electron transport process in the catalyst. Adding carbon black particles $\left(\right.$ Vulcan $\left.{ }^{\circledR}\right)$ to amorphous $\mathrm{MoS}_{3}$ particles improved the conductivity of the system, resulting in a lower Tafel slope and an absence of the $45^{\circ}$ line in the Nyquist impedance plot. Alternatively, more conductive amorphous molybdenum sulfide particles could be prepared by chemical reduction of $\left[\mathrm{MoS}_{4}\right]^{2-}$ with $\mathrm{NaBH}_{4}$. The resulting particles have XPS spectra similar to $\mathrm{MoS}_{2+\mathrm{x}}$ and have an apparent Tafel slope of less than $40 \mathrm{mV} / \mathrm{dec}$ at both low and high loadings (Table 1).

PHOTOELECTROCHEMICAL HYDROGEN EVOLUTION FROM COPPER(I) OXIDE COATED WITH

a)

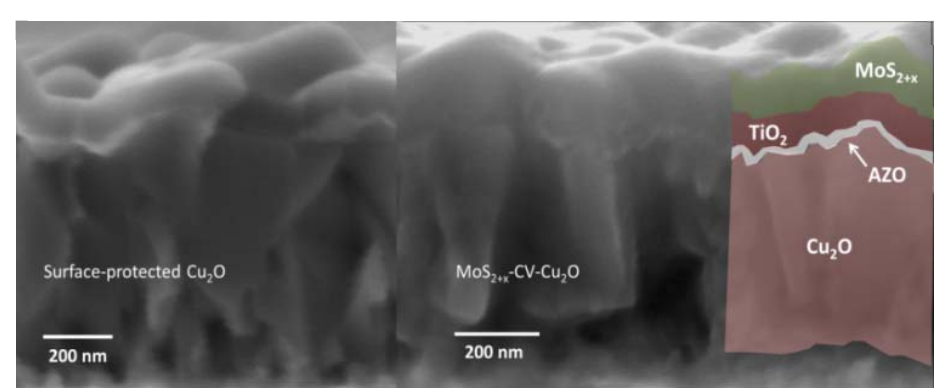

b)

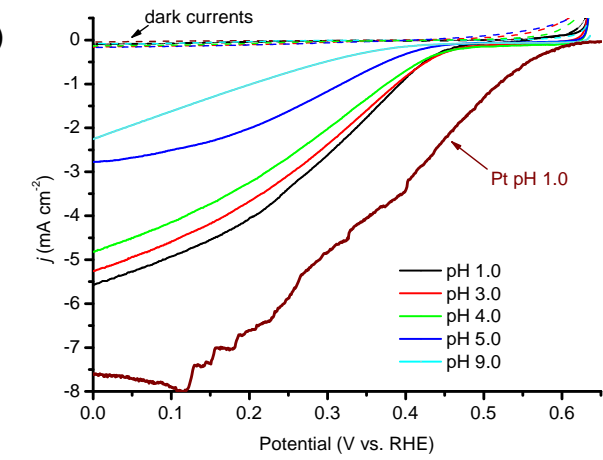

c)

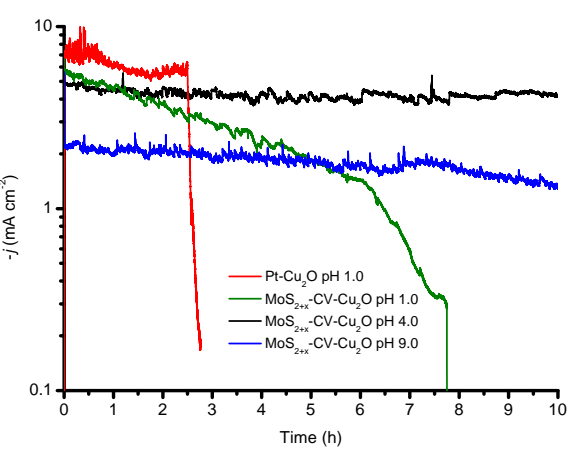

\section{AN AMORPHOUS \\ MOLYBDENUM \\ SULFIDE}

The amorphous molybdenum sulfide catalysts, especially the electrodeposited films, exhibit many features that are attractive for photoelectrochemical hydrogen evolution: they can be deposited under ambient conditions using readily available and inexpensive precursors, they have high HER activity and stability, and they are optically rather transparent. Therefore, we collaborated with the Grätzel group in our institute to apply the $\mathrm{MoS}_{2+\mathrm{x}}$ catalyst to promote the photoelectrochemical hydrogen evolution on $\mathrm{Cu}_{2} \mathrm{O}{ }^{32}$ Surface-protected cuprous oxide is arguably the state-of-the-art p-type oxide for photoelectrochemical hydrogen evolution. ${ }^{33}$ It has a direct band gap of 2 $\mathrm{eV}$ and can produce a maximum photocurrent of $14.7 \mathrm{~mA} / \mathrm{cm}^{2}$ and maximum solar to hydrogen efficiency of $18 \%$ under 1 sun irradiation. $\mathrm{Pt}^{34}$ and $\mathrm{RuO}_{2}{ }^{35}$ had been used as the HER catalysts for $\mathrm{Cu}_{2} \mathrm{O}$ in earlier studies.

The deposition of molybdenum sulfide catalyst was achieved by photoelectrochemistry utilizing unfiltered irradiation from a Xe lamp. Under illumination, photons with energy greater than the band gap of $\mathrm{Cu}_{2} \mathrm{O}$ are absorbed to generate electron-hole pairs in the metal oxide photoelectrode. Engineering of a $\mathrm{p}$-n junction between the $\mathrm{p}$-type cuprous oxide and a thin layer of n-type Al-doped $\mathrm{ZnO}(\mathrm{AZO})$ reduces electron-hole recombination and facilitates the extraction of electrons from the photoelectrode. Excited electrons are driven through the $\mathrm{TiO}_{2}$ protective layer and into the semiconductor/electrolyte interface. Exited electrons reaching the electrolyte solution have enough chemical potential to drive the reductive deposition of $\mathrm{MoS}_{2}$ (eq 3 in Figure 2). The unfiltered irradiation has a small fraction of photons with enough energy to create holes in the $\mathrm{TiO}_{2}$ that under the applied bias drives the oxidative deposition of $\mathrm{MoS}_{3}$ (eq 1 in Figure 2). Overall, 
the photoelectrochemical deposition of the $\mathrm{MoS}_{2+\mathrm{x}}$ catalyst is analogous to the electrochemical deposition of the same catalyst in the dark. Figure 8a shows the surface protected $\mathrm{Cu}_{2} \mathrm{O}$ before and after the deposition of $100 \mathrm{~nm}$ thick catalyst.

The $\mathrm{MoS}_{2+\mathrm{x}}-\mathrm{Cu}_{2} \mathrm{O}$ photocathodes were tested for hydrogen evolution under simulated AM 1.5 illumination (100 $\mathrm{mW} / \mathrm{cm}^{2}$ ). Figure $8 \mathrm{~b}$ displays the current-potential curves in the dark and under illumination for a $\mathrm{MoS}_{2+x}-\mathrm{Cu}_{2} \mathrm{O}$ photocathode with a catalyst loading of $30 \mu \mathrm{g} / \mathrm{cm}^{2}$. A photocurrent of $-5.7 \mathrm{~mA} / \mathrm{cm}^{2}$ at $0 \mathrm{~V}$ vs. RHE was obtained at $\mathrm{pH}=1$. The onset potential is $150 \mathrm{mV}$ more negative than that observed for an analogous photocathode with $\mathrm{Pt}$ nanoparticles as HER catalyst. However, the deposition of the conformal film protects the photocathode from corrosion in acid, improving the stability of the photoelectrode relative to analogous device coated with $\mathrm{Pt}$ nanoparticles (Figure 8c). The $\mathrm{MoS}_{2+\mathrm{x}}-\mathrm{Cu}_{2} \mathrm{O}$ photoelectrode is also stable and active at neutral and basic $\mathrm{pH}$. Stable currents of -4 and $-2 \mathrm{~mA} / \mathrm{cm}^{2}$ were obtained at $0 \mathrm{~V}$ vs. RHE at $\mathrm{pH}=4$ and 9 , respectively, for $10 \mathrm{~h}$. The photoelectrochemical hydrogen evolution has a nearly quantitative Faradaic efficiency.

The catalyst loading can be varied from 10 to $100 \mu \mathrm{g} / \mathrm{cm}^{2}$; the catalyst can be deposited in surface areas in the order of several square centimeters. Figure $8 \mathrm{~d}$ shows a digital image of the surface-protected $\mathrm{Cu}_{2} \mathrm{O}$ after deposition of the $\mathrm{MoS}_{2+\mathrm{x}}$ catalyst on the area exposed to light. This layered device is the most active and stable $\mathrm{Cu}_{2} \mathrm{O}$ photoelectrode that makes use of an earth-abundant HER catalyst.

RELATED SYNTHESIS AND APPLICATION OF AMORPHOUS MOLYBDENUM SULFIDE CATALYSTS

Since our initial report in 2011, several other groups have worked in the development of analogous amorphous molybdenum sulfide catalysts. Benck et al. reported the synthesis of amorphous molybdenum sulfide particles from a solution of ammonium heptamolybdate, sodium sulfide, and sulfuric acid. The resulting catalyst has properties and activity similar to our chemically prepared $\mathrm{MoS}_{3}$ precatalyst. ${ }^{36}$ Laursen et al. electrochemically deposited amorphous $\mathrm{MoS}_{2+\mathrm{x}}$ films on activated carbon paper to achieve higher mechanical stability of the catalyst. ${ }^{37}$ Hsu et al. prepared amorphous molybdenum sulfide particles by low temperature thermolysis of an ammonium tetratiomolybdate precursor. Addition of $\mathrm{NbCl}_{5}$ during the preparation of catalyst resulted in enhancement of HER activity. ${ }^{38}$ The same group also deposited amorphous molybdenum sulfide catalysts on high surface area, three-dimensional electrodes for electrochemical hydrogen production using this thermolysis method. ${ }^{39,40}$

A number of highly active amorphous HER catalysts are recently developed using electrochemical deposition methods similar to the one developed for the deposition of amorphous molybdenum sulfide film catalysts. ${ }^{41-43}$ Tram et al. reported the electrodeposition of ternary sulfides of cobalt-tungsten and nickel-tungsten which showed good HER activity. ${ }^{42}$ Wang et al. reported a simple, one-step electrochemical copolymerization method to fabricate a hybrid film containing polypyrrole (PPy), a conductive polymer, and amorphous molybdenum sulfide catalyst. The hybrid system exhibited a remarkable HER activity. ${ }^{43}$ Sun et al. reported the electrochemical synthesis of amorphous Co-S catalyst that worked best in neutral water. ${ }^{41}$

Our amorphous $\mathrm{MoS}_{2+\mathrm{x}}$ catalysts has also been adapted by other groups for photoelectrochemical hydrogen evolution. Seger et al. deposited the $\mathrm{MoS}_{2+\mathrm{x}}$ film catalyst on a Si photoelectrode protected with a Ti layer. ${ }^{44}$ The resulting photocathode gave an impressive photocurrent under illumination. The same group also deposited this catalyst to $\mathrm{Si}$ photocathodes protected by a thin $\mathrm{MoS}_{2}$ layer. ${ }^{45}$ Tran et al. reported similar work to use the $\mathrm{MoS}_{2+\mathrm{x}}$ film catalyst for photoelectrochemical hydrogen evolution on silicon nanowires. ${ }^{46}$ Bourgeteau et al. applied the amorphous $\mathrm{MoS}_{3}$ particles as HER catalyst to an organic solar cell for photoelectrochemical hydrogen evolution in acidic solutions. ${ }^{47}$ In a related work, Tang et al. deposited an amorphous molybdenum sulfide catalyst on CdSe-seeded $\mathrm{CdS}$ nanorods by microwave thermolysis of $\left(\mathrm{NH}_{4}\right)_{2} \mathrm{MoS}_{4}{ }^{48}$ Characterization of the catalyst by XPS and extended X-ray absorption fine structure (EXAFS) spectroscopy revealed an active catalyst similar to our $\mathrm{MoS}_{2+\mathrm{x}}$ species. The catalyst promoted the photochemical hydrogen production from a buffered aqueous solution $(\mathrm{pH}=7)$ using triethanolamine as the sacrificial electron donor.

\section{CONCLUSION AND PERPECTIVES}

Summing up, we have established amorphous molybdenum sulfides as a new class of non-precious HER catalysts. These catalysts can be conveniently synthesized either by electro-

Table 1. Summary of electrochemical HER parameters of amorphous molybdenum sulfide catalysts developed in our group.

\begin{tabular}{|c|c|c|c|c|}
\hline catalyst & $\begin{array}{l}\text { preparation method } \\
\text { (substrate) }\end{array}$ & catalyst loading / mg/ $\mathrm{cm}^{2}$ & $\begin{array}{c}\eta_{\mathrm{j}=10 \mathrm{~mA} / \mathrm{cm}^{2}} / \mathrm{mV} \\
\mathrm{pH}=0\end{array}$ & $\begin{array}{c}\text { Tafel slope } / \mathrm{mV} / \mathrm{dec} \\
\mathrm{pH}=0\end{array}$ \\
\hline $\mathrm{MoS}_{2+\mathrm{x}}$ film $^{a}$ & $\begin{array}{l}\text { electrochemical } \\
\text { (rotating disk GC) }\end{array}$ & 0.2 & 160 & 40 \\
\hline M-MoS ${ }_{2+x}$ film $^{b}$ & $\begin{array}{l}\text { electrochemical } \\
\text { (GC) }\end{array}$ & $0.013-0.014^{\mathrm{e}}$ & $181-192$ & $39-43$ \\
\hline \multirow{2}{*}{$\mathrm{MoS}_{3}$ particles $^{c}$} & chemical synthesis & 0.282 & 220 & 63 \\
\hline & $(\mathrm{GC})$ & 0.028 & 235 & 45 \\
\hline \multirow{2}{*}{$\mathrm{MoS}_{2+\mathrm{x}}$ particles $^{d}$} & chemical reduction & 0.252 & 200 & 35 \\
\hline & $\left(\right.$ Vulcan $\left.^{\circledR}\right)$ & 0.025 & 225 & 36 \\
\hline
\end{tabular}

${ }^{a}$ Deposited by cyclic voltammetry from a $\left[\mathrm{MoS}_{4}\right]^{2-}$ precursor solution. ${ }^{21}{ }^{b}$ Deposition from a bath containing a $1: 3$ ratio of $\mathrm{MCl}_{2}$ to $\left(\mathrm{NH}_{4}\right)_{2}\left[\mathrm{MoS}_{4}\right]$ by cyclic voltammetry, where $\mathrm{M}=\mathrm{Fe}, \mathrm{Co}, \mathrm{Ni}^{24}{ }^{\mathrm{c}} \mathrm{Chemical}$ synthesis through acidification of a solution of $\mathrm{MoO}_{3}$ and $\mathrm{Na}_{2} \mathrm{~S} .{ }^{29,30}$ Chemical reduction of $\left[\mathrm{MoS}_{4}\right]^{2-}$ with $\mathrm{NaBH}_{4}{ }^{30}$ e Loading of Mo. 
deposition or by a wet, chemical process. The mechanism for the electrodeposition has been unveiled and the active species has been identified as $\mathrm{MoS}_{2+\mathrm{x}}$. The catalysts exhibit remarkable HER activity, especially in acidic solutions, rivaling the best known catalysts that are composed of only earth-abundant elements. Table 1 summarizes important performance parameters (i.e. apparent Tafel slope, catalyst loading and overpotential necessary to produce a current density of $10 \mathrm{~mA} / \mathrm{cm}^{2}$ ) for the amorphous molybdenum sulfide systems developed in our group and described in this account.

Parallel to our work, a large amount of research efforts have been invested in the development of nanostructured and single crystalline $\mathrm{MoS}_{2}$ nanoparticles. ${ }^{12}$ While our amorphous catalysts have similar activity to the best $\mathrm{MoS}_{2}$ nanocrystals, they can be prepared under ambient conditions using solutionbased methods. The $\mathrm{MoS}_{2}$ nanocrystals, on the other hand, are normally prepared under elevated temperature, pressure, or vacuum. Clearly, the amorphous molybdenum sulfide catalysts are more processable and scalable. This aspect is demonstrated in several applications of the amorphous catalysts in photoelectrochemical hydrogen evolution including our own work on $\mathrm{MoS}_{2+\mathrm{x}}$-coated $\mathrm{Cu}_{2} \mathrm{O}$ photocathodes.

The production of solar fuels is a grand technical challenge that has inspired numerous scientific endeavors. Not all work will lead to the ultimate solutions, if such a solution exists. Likewise, not all promising catalysts including the amorphous molybdenum sulfide catalysts described here may end up being used in an actual energy conversion device. The broader implication of our research in this field, however, is the concept of using amorphous materials as catalysts for hydrogen evolution. Amorphous materials are often accessible through simple solution-based synthesis under relatively mild conditions. The structural disorder in these materials might be detrimental to their electronic and photonic properties, but for catalytic applications, the resulting defect sites may serve as efficient reaction centers. We expect an emergence of amorphous catalysts for solar fuel production in the near future. The difficulty in the characterization and understanding of such catalysts will motivate the development of new analytical tools in catalysis.

\section{AUTHOR INFORMATION}

\section{Corresponding Author}

* Corresponding author. E-mail: xile.hu@epfl.ch; Tel. +41 21693 9781.

\section{Notes}

The authors declare no competing financial interest.

\section{Biographies}

Carlos G. Morales-Guio was born in Nobsa, Colombia. He obtained a bachelor's degree in Chemical Engineering from Osaka University in 2011, where he was a Monbukagakusho Scholar. He then obtained a master's degree in Chemical Engineering and Biotechnology at the Ecole Polytechnique Fédérale de Lausanne (EPFL) in 2013. Currently, he is a Ph.D. student in Prof. Xile Hu's group at EPFL. His research focuses on the coupling of earthabundant electrocatalysts to photoelectrodes for efficient solar fuel production.
Xile Hu was born in 1978 in Putian, China. He received a B.S. degree from Peking University (2000) and a Ph.D. degree from the University of California, San Diego (2004; advisor: Prof. Karsten Meyer). He carried out a postdoctoral study at the California Institute of Technology (advisor: Prof. Jonas Peters) before joining the École Polytechnique Fédérale de Lausanne (EPFL) as a tenure-track assistant professor in 2007. He is currently associate professor at the same institute. His research interests span from organometallic chemistry, synthetic methodology, and reaction mechanism to bio-mimetic and bio-speculated coordination chemistry to electrocatalysis and artificial photosynthesis.

\section{ACKNOWLEDGMENT}

Dedicated to Professor Michael Grätzel on the occasion of his $70^{\text {th }}$ birthday. This work is supported by a starting grant from the European Research Council under the European Community's Seventh Framework Programme (FP7 2007-2013)/ERC Grant agreement no. 257096. We thank our co-workers, especially Dr. Daniel Merki and Dr. Heron Vrubel, for their contributions in this project.

\section{REFERENCES}

(1) Gratzel, M. Photoelectrochemical cells. Nature 2001, 414, 338-344.

(2) Lewis, N. S.; Nocera, D. G. Powering the planet: Chemical challenges in solar energy utilization. Proc. Natl. Acad. Sci. USA 2006, 103, 15729-15735.

(3) Momirlan, M.; Veziroglu, T. N. The properties of hydrogen as fuel tomorrow in sustainable energy system for a cleaner planet. Int. J. Hydrogen Energy 2005, 30, 795-802.

(4) Joshi, A. S.; Dincer, I.; Reddy, B. V. Exergetic assessment of solar hydrogen production methods. Int. J. Hydrogen Energy 2010, 35, 4901-4908.

(5) Pinaud, B. A.; Benck, J. D.; Seitz, L. C.; Forman, A. J.; Chen, Z. B.; Deutsch, T. G.; James, B. D.; Baum, K. N.; Baum, G. N.; Ardo, S.; Wang, H. L.; Miller, E.; Jaramillo, T. F. Technical and economic feasibility of centralized facilities for solar hydrogen production via photocatalysis and photoelectrochemistry. Energy Environ. Sci. 2013, 6, 1983-2002.

(6) Photoelectrochemical hydrogen production; Springer US: New York, USA, 2012; Vol. 102.

(7) Hinnemann, B.; Moses, P. G.; Bonde, J.; Jørgensen, K. P.; Nielsen, J. H.; Horch, S.; Chorkendorff, I.; Nørskov, J. K. Biomimetic hydrogen evolution: $\mathrm{MoS}_{2}$ nanoparticles as catalyst for hydrogen evolution. J. Am. Chem. Soc. 2005, 127, 5308-5309.

(8) Nørskov, J. K.; Bligaard, T.; Logadottir, A.; Kitchin, J. R.; Chen, J. G.; Pandelov, S.; Stimming, U. Trends in the exchange current for hydrogen evolution. J. Electrochem. Soc. 2005, 152, J23-J26.

(9) Jaramillo, T. F.; Jørgensen, K. P.; Bonde, J.; Nielsen, J. H.; Horch, S.; Chorkendorff, I. Identification of active edge sites for electrochemical $\mathrm{H}_{2}$ evolution from $\mathrm{MoS}_{2}$ nanocatalysts. Science 2007, 317, 100-102.

(10) Li, Y.; Wang, H.; Xie, L.; Liang, Y.; Hong, G.; Dai, H. $\mathrm{MoS}_{2}$ nanoparticles grown on graphene: An advanced catalyst for the hydrogen evolution reaction. J. Am. Chem. Soc. 2011, 133, 7296-7299.

(11) Wang, H.; Lu, Z.; Xu, S.; Kong, D.; Cha, J. J.; Zheng, G.; Hsu, P.-C.; Yan, K.; Bradshaw, D.; Prinz, F. B.; Cui, Y. Electrochemical tuning of vertically aligned $\mathrm{MoS}_{2}$ nanofilms and its application in improving hydrogen evolution reaction. Proc. Natl. Acad. Sci. USA 2013.

(12) Morales-Guio, C. G.; Stern, L.-A.; Hu, X. Nanostructured hydrotreating catalysts for electrochemical hydrogen evolution. Chem. Soc. Rev. 2014. 
(13) Laursen, A. B.; Kegnaes, S.; Dahl, S.; Chorkendorff, I. Molybdenum sulfides-efficient and viable materials for electro and photoelectrocatalytic hydrogen evolution. Energy Environ. Sci. 2012, 5, 5577-5591.

(14) Merki, D.; Hu, X. Recent developments of molybdenum and tungsten sulfides as hydrogen evolution catalysts. Energy Environ. Sci. 2011, 4, 3878-3888.

(15) Yan, Y.; Xia, B.; Xu, Z.; Wang, X. Recent development of molybdenum sulfides as advanced electrocatalysts for hydrogen evolution reaction. ACS catal. 2014, 1693-1705.

(16) Weber, T.; Muijsers, J. C.; Niemantsverdriet, J. W. Structure of amorphous $\mathrm{MoS}_{3}$. J. Phys. Chem. 1995, 99, 91949200.

(17) Hibble, S. J.; Rice, D. A.; Pickup, D. M.; Beer, M. P. Mo K-edge EXAFS and $\mathrm{S}$ K-edge absorption studies of the amorphous molybdenum Sulfides $\mathrm{MoS}_{4.7}, \mathrm{MoS}_{3}$, and $\mathrm{MoS}_{3} n \mathrm{H}_{2} \mathrm{O}$ $(n \sim 2)$. Inorg. Chem. 1995, 34, 5109-5113.

(18) Merki, D.; Fierro, S.; Vrubel, H.; Hu, X. L. Amorphous molybdenum sulfide films as catalysts for electrochemical hydrogen production in water. Chem. Sci. 2011, 2, 1262-1267.

(19) Merki, D. A.; Hu, X. PhD thesis, Ecole Polytechnique Fédérale de Lausanne, 2012.

(20) Bonde, J.; Moses, P. G.; Jaramillo, T. F.; Norskov, J. K.; Chorkendorff, I. Hydrogen evolution on nano-particulate transition metal sulfides. Farad. Discuss. 2009, 140, 219-231.

(21) Vrubel, H.; Hu, X. Growth and activation of an amorphous molybdenum sulfide hydrogen evolving catalyst. ACS catal. 2013, 3, 2002-2011.

(22) Belanger, D.; Laperriere, G.; Girard, F.; Guay, D.; Tourillon, G. Physicochemical characteristics of electrochemically deposited molybdenum sulfide and polypyrrole tetrathiomolybdate molybdenum trisulfide composite electrodes. Chem. Mater. 1993, 5, 861-868.

(23) Ponomarev, E. A.; Neumann-Spallart, M.; Hodes, G.; Lévy-Clément, C. Electrochemical deposition of $\mathrm{MoS}_{2}$ thin films by reduction of tetrathiomolybdate. Thin Solid Films 1996, 280, 86-89.

(24) Merki, D.; Vrubel, H.; Rovelli, L.; Fierro, S.; Hu, X. Fe, $\mathrm{Co}$, and $\mathrm{Ni}$ ions promote the catalytic activity of amorphous molybdenum sulfide films for hydrogen evolution. Chem. Sci. 2012, 3, 2515-2525.

(25) Topsøe, H.; Clausen, B.; Massoth, F. In Catalysis; Anderson, J., Boudart, M., Eds.; Springer Berlin Heidelberg, 1996; Vol. 11; pp 1-269.

(26) The films are labeled $\mathrm{M}-\mathrm{MoS}_{2+\mathrm{x}}$ films here rather than M$\mathrm{MoS}_{3}$ in the original paper. This is because the active catalyst in various amorphous molybdenum sulfide catalysts is now known to be $\mathrm{MoS}_{2+\mathrm{x}}$. In the original paper, the $\mathrm{MoS}_{3}$ label was referred to the precatalyst.

(27) Besenbacher, F.; Brorson, M.; Clausen, B. S.; Helveg, S.; Hinnemann, B.; Kibsgaard, J.; Lauritsen, J. V.; Moses, P. G.; Nørskov, J. K.; Topsøe, H. Recent STM, DFT and HAADFSTEM studies of sulfide-based hydrotreating catalysts: Insight into mechanistic, structural and particle size effects. Catal. Today 2008, 130, 86-96.

(28) Afanasiev, P. Synthetic approaches to the molybdenum sulfide materials. C. R. Chimie 2008, 11, 159-182.

(29) Vrubel, H.; Merki, D.; Hu, X. Hydrogen evolution catalyzed by $\mathrm{MoS}_{3}$ and $\mathrm{MoS}_{2}$ particles. Energy Environ. Sci. 2012, 5, 6136-6144.

(30) Vrubel, H.; Moehl, T.; Gratzel, M.; Hu, X. Revealing and accelerating slow electron transport in amorphous molybdenum sulphide particles for hydrogen evolution reaction. Chem. Commun. 2013, 49, 8985-8987.

(31) Fabregat-Santiago, F.; Bisquert, J.; Garcia-Belmonte, G.; Boschloo, G.; Hagfeldt, A. Influence of electrolyte in transport and recombination in dye-sensitized solar cells studied by impedance spectroscopy. Sol. Energy Mater. Sol. Cells 2005, 87, 117-131.

(32) Morales-Guio, C. G.; Tilley, S. D.; Vrubel, H.; Gratzel, M.; $\mathrm{Hu}, \mathrm{X}$. Hydrogen evolution from a copper(I) oxide photocathode coated with an amorphous molybdenum sulphide catalyst. Nat. Commun. 2014, 5, 3059.

(33) Prévot, M. S.; Sivula, K. Photoelectrochemical tandem cells for solar water splitting. J. Phys. Chem. C 2013, 117, 1787917893.

(34) Paracchino, A.; Laporte, V.; Sivula, K.; Gratzel, M.; Thimsen, E. Highly active oxide photocathode for photoelectrochemical water reduction. Nat. Mater. 2011, 10, 456461.

(35) Tilley, S. D.; Schreier, M.; Azevedo, J.; Stefik, M.; Graetzel, M. Ruthenium oxide hydrogen evolution catalysis on composite cuprous oxide water-splitting photocathodes. Adv. Funct. Mater. 2014, 24, 303-311.

(36) Benck, J. D.; Chen, Z. B.; Kuritzky, L. Y.; Forman, A. J.; Jaramillo, T. F. Amorphous molybdenum sulfide catalysts for electrochemical hydrogen production: Insights into the origin of their catalytic activity. ACS catal. 2012, 2, 1916-1923.

(37) Laursen, A. B.; Vesborg, P. C. K.; Chorkendorff, I. A highporosity carbon molybdenum sulphide composite with enhanced electrochemical hydrogen evolution and stability. Chem. Commun. 2013, 49, 4965-4967.

(38) Hsu, C.-L.; Chang, Y.-H.; Chen, T.-Y.; Tseng, C.-C.; Wei, K.-H.; Li, L.-J. Enhancing the electrocatalytic water splitting efficiency for amorphous $\mathrm{MoS}_{\mathrm{x}}$. Int. J. Hydrogen Energy 2014, 39, 4788-4793

(39) Chang, Y.-H.; Lin, C.-T.; Chen, T.-Y.; Hsu, C.-L.; Lee, Y.H.; Zhang, W.; Wei, K.-H.; Li, L.-J. Highly efficient electrocatalytic hydrogen production by $\mathrm{MoS}_{\mathrm{x}}$ grown on graphene-protected 3D Ni foams. Adv. Mater. 2013, 25, 756-760.

(40) Chang, Y.-H.; Wu, F.-Y.; Chen, T.-Y.; Hsu, C.-L.; Chen, C.-H.; Wiryo, F.; Wei, K.-H.; Chiang, C.-Y.; Li, L.-J. Threedimensional molybdenum sulfide sponges for electrocatalytic water splitting. Small 2014, 10, 895-900.

(41) Sun, Y. J.; Liu, C.; Grauer, D. C.; Yano, J. K.; Long, J. R.; Yang, P. D.; Chang, C. J. Electrodeposited cobalt-sulfide catalyst for electrochemical and photoelectrochemical hydrogen generation from water. J. Am. Chem. Soc. 2013, 135, 1769917702.

(42) Tran, P. D.; Chiam, S. Y.; Boix, P. P.; Ren, Y.; Pramana, S. S.; Fize, J.; Artero, V.; Barber, J. Novel cobalt/nickel-tungstensulfide catalysts for electrocatalytic hydrogen generation from water. Energy Environ. Sci. 2013, 6, 2452-2459.

(43) Wang, T.; Zhuo, J.; Du, K.; Chen, B.; Zhu, Z.; Shao, Y.; Li, M. Electrochemically fabricated polypyrrole and $\mathrm{MoS}_{\mathrm{x}}$ copolymer films as a highly active hydrogen evolution electrocatalyst. Adv. Mater. 2014, 26, 3761-3766.

(44) Seger, B.; Laursen, A. B.; Vesborg, P. C. K.; Pedersen, T.; Hansen, O.; Dahl, S.; Chorkendorff, I. Hydrogen production using a molybdenum sulfide catalyst on a titanium-protected $\mathrm{n}^{+} \mathrm{p}$-silicon photocathode. Angew. Chem. Int. Ed. 2012, 51, 9128-9131.

(45) Laursen, A. B.; Pedersen, T.; Malacrida, P.; Seger, B.; Hansen, O.; Vesborg, P. C. K.; Chorkendorff, I. MoS ${ }_{2}$-an integrated protective and active layer on $\mathrm{n}^{+} \mathrm{p}-\mathrm{Si}$ for solar $\mathrm{H}_{2}$ evolution. PCCP 2013, 15, 20000-20004.

(46) Tran, P. D.; Pramana, S. S.; Kale, V. S.; Nguyen, M.; Chiam, S. Y.; Batabyal, S. K.; Wong, L. H.; Barber, J.; Loo, J. Novel assembly of an $\mathrm{MoS}_{2}$ electrocatalyst onto a silicon nanowire array electrode to construct a photocathode composed of elements abundant on the earth for hydrogen generation. Chem. Eur. J. 2012, 18, 13994-13999.

(47) Bourgeteau, T.; Tondelier, D.; Geffroy, B.; Brisse, R.; Laberty-Robert, C.; Campidelli, S.; de Bettignies, R.; Artero, V.; Palacin, S.; Jousselme, B. A $\mathrm{H}_{2}$-evolving photocathode based on 
direct sensitization of $\mathrm{MoS}_{3}$ with an organic photovoltaic cell. Energy Environ. Sci. 2013, 6, 2706-2713.

(48) Tang, M. L.; Grauer, D. C.; Lassalle-Kaiser, B.; Yachandra, V. K.; Amirav, L.; Long, J. R.; Yano, J.; Alivisatos, A. P. Structural and electronic study of an amorphous $\mathrm{MoS}_{3}$ hydrogen-generation catalyst on a quantum-controlled photosensitizer. Angew. Chem. Int. Ed. 2011, 50, 10203-10207. 
For Table of Contents Only

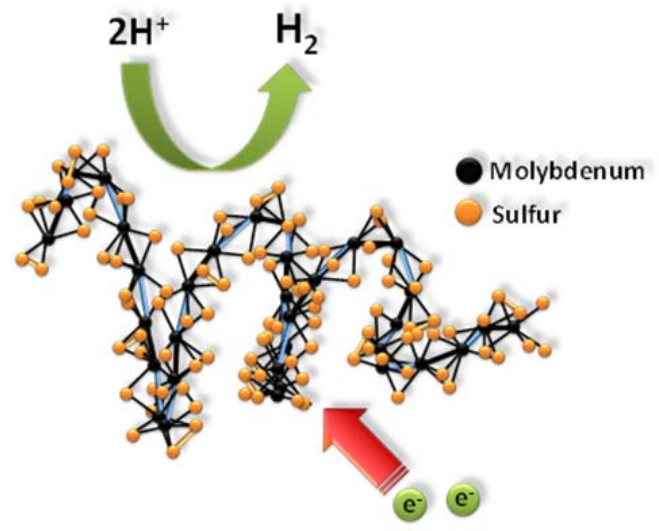

